\title{
Inundation maps for extreme flood events: Case study of Sidi Bel Abbes city, Algeria
}

\author{
M'hamed ATALLAH ${ }^{1)}$ ABCDEF $\bowtie$, Abdelkrim HAZZAB ${ }^{2)}$ ADE, \\ Abdelali SEDDINI ${ }^{3) \text { AD }}$, Abdellah GHENAIM ${ }^{4) \text { AD }}$, Khaled KORICHI ${ }^{2) ~ B F}$
}

\footnotetext{
${ }^{1)}$ Nour Bachir University, Department of Technology, El-Bayadh University Center, BP 900, 32000, Algeria; e-mail: mhamed.atallah.dz@gmail.com

2) Taher Moulay University of Saida, Modeling and Computational Methods Laboratory, Saïda, Algeria; e-mail: hazzabdz@yahoo.fr,kh.korichi@gmail.com

3) Tlemcen University, Department of Hydraulics, Faculty of Engineering, Tlemcen, Algeria; e-mail: abdelseddini@yahoo.fr

4) Laboratory of Mechanics and Environment ICUBE / INSA, National Institute of the Applied Sciences, Strasbourg, France; e-mail: abdellah.ghenaim@insa-strasbourg.fr
}

For citation: Atallah M., Hazzab A., Seddini A., Ghenaim A., Korichi K. 2018. Inundation maps for extreme flood events: Case study of Sidi Bel Abbes city, Algeria. Journal of Water and Land Development. No. 37 p. 19-27. DOI: 10.2478/jwld-2018-0021.

\begin{abstract}
Hydrodynamic modelling is used to analyse the inundation behaviour of Sidi Bel Abbes city (North-West of Algeria) during extreme flood events. The study reach, $5.4 \mathrm{~km}$ in length, is a section of Wadi Mekerra through Sidi Bel Abbes city. Land and bathymetric surveys were used to create a digital terrain model (DTM) of the river channel and the floodplain. By coupling the geometry with hydrologic data, a two dimensional hydrodynamic model was built. The model is based on integrating Saint-Venant shallow waters (depth averaged) equations through Runge-Kutta discontinuous Galerkin numerical scheme. It was calibrated in terms of roughness coefficients on measured values of water surface elevation and discharge registered in the Sidi Bel Abbes gauging station. The objective is to draw the flood maps under extreme river flood event. The results are helpful for local authorities in order to take the appropriate defence measures in the future.
\end{abstract}

Key words: flood, inundation maps, Runge-Kutta discontinuous Galerkin, Saint-Venant equations, Wadi Mekerra

\section{INTRODUCTION}

Flood is the most expensive and devastating natural hazard accounted for $40 \%$ of the total number of natural disasters that occurred around the world between 1985 and 2009 [DEWAN 2013]. They are responsible for a third of the overall economic loss and for over half the fatalities [BERZ 2000]. During the last decade of the twentieth century, floods killed 100,000 people and affected 1.4 billion people over the world [JONKMAN 2005]. Algeria experienced several flood disasters. According to civil protection, 485
(1/3 of 1541$)$ inhabited areas are recognized as floodprone areas at different risk levels [SARDOU et al. 2016]. The flood that affected Bab El Oued district (Algiers) on 10 November 2001 caused one of the most unique and worst disasters that leaded to 750 fatalities, 115 missing persons, 30,000 people left homeless, in addition to net economic damages of over 250 million euro. Floods in Mekerra Basin, North-West of Algeria affect more than 200,000 residents in this region. From 1986 to 2007, floods have caused extensive damage, 10 dead and 929 homeless families are reported by ATALLAH et al. [2016]. 
Future flood impacts can be limited through structural flood control measures such as construction of dams or river dikes and non-structural measures such as flood hazard and risk management and emergency preparedness and insurance. Modelling and simulation of flood events are necessary to understand the mechanisms of the process and therefore play a central role in the evaluation, selection and in some cases the implementation of these measures [SCHUBERT, SANDERS 2012]. The information provided from simulations about potential floods must include such data as (i) time of the flood wave arrival at some points in a valley or a city, (ii) extreme water levels in the flooded area, (iii) duration and range of flooding and (iv) water depths and velocities in the flooded zones [DELIS, KAMPANIS 2009]. These informations which can be obtained by solving the SAINT-VENANT [1871] equations are used to develop the flood inundations maps. These maps can be used as a tool to picture the most significant vulnerable areas, where stakeholders, governments, and decision-makers should focus their investments.

The aim of this study is to analyse the flooding behaviour of a study area situated in Sidi Bel Abbes city (North-West of Algeria), for real flood events. For this purpose, a 2D hydraulic model was set up with the help of Runge-Kutta discontinuous Galerkin (RKDG) finite element scheme. In this context, the objective of the present study is to draw the flood maps under extreme river flood event. The results are helpful for local authorities in order to take the appropriate defence measures in the future.

\section{METHODS}

\section{STUDY AREA}

The Wadi Mekerra basin in the North-West of Algeria (Fig. 1) represents one of the semi-arid re- gions the most affected by floods and has been always one of the main concerns of managers in Sidi Bel Abbes province. A global description and general information about the study site, flow regime and the chronology of floods generated at Wadi Mekerra are detailed in previous study performed by ATALLAH et al. [2016].

The floods are stronger and more frequent during autumn months than any other season. Figure 2 shows the peak annual discharges of historic floods measured at Sidi Bel Abbes gauging station between 1942 and 2006. The annual instantaneous peak discharge values vary considerably from one year to another due to the irregularity of the annual rainfall intensity also influenced by the type of climate in our region (semiarid). An increase in the magnitude of flood has been observed between 1990 and 2006. The Wadi Mekerra emerges downstream in the alluvial plain of Sidi Bel Abbes with a very weak slope $(0.3-0.8 \%)$ generating floods and therefore, causing extreme damage in Sidi Bel Abbes city. Table 1 summarizes the major floods occurred between 1986-2000 that caused flooding in Sidi Bel Abbes city.

Wadi Mekerra is an ephemeral river [ATALLAH et al. 2016; KORICHI et al. 2016]. Flow occurs only for a short period during and after rainstorms. During flood, the average multiannual Wadi flow (19422006) measured at Sidi Bel Abbes gauging station is

Table 1. Human losses related to flood events occurred at Sidi Bel Abbes city (1986-2000)

\begin{tabular}{|l|c|c|c|}
\hline \multirow{2}{*}{ Date } & \multicolumn{2}{|c|}{ Number of casualties } & Maximum recorded \\
\cline { 2 - 3 } & dead & $\begin{array}{c}\text { homeless } \\
\text { families }\end{array}$ & $\begin{array}{c}\text { discharge } \\
\mathrm{m}^{3} \cdot \mathrm{s}^{-1}\end{array}$ \\
\hline October 4,1986 & 1 & 200 & 104 \\
\hline April 30, 1990 & 2 & 130 & not given \\
\hline September 29,1994 & 2 & 22 & 215 \\
\hline September 27, 1997 & 1 & - & 170 \\
\hline October 23, 2000 & 1 & 7 & 161.8 \\
\hline
\end{tabular}

Source: own elaboration.
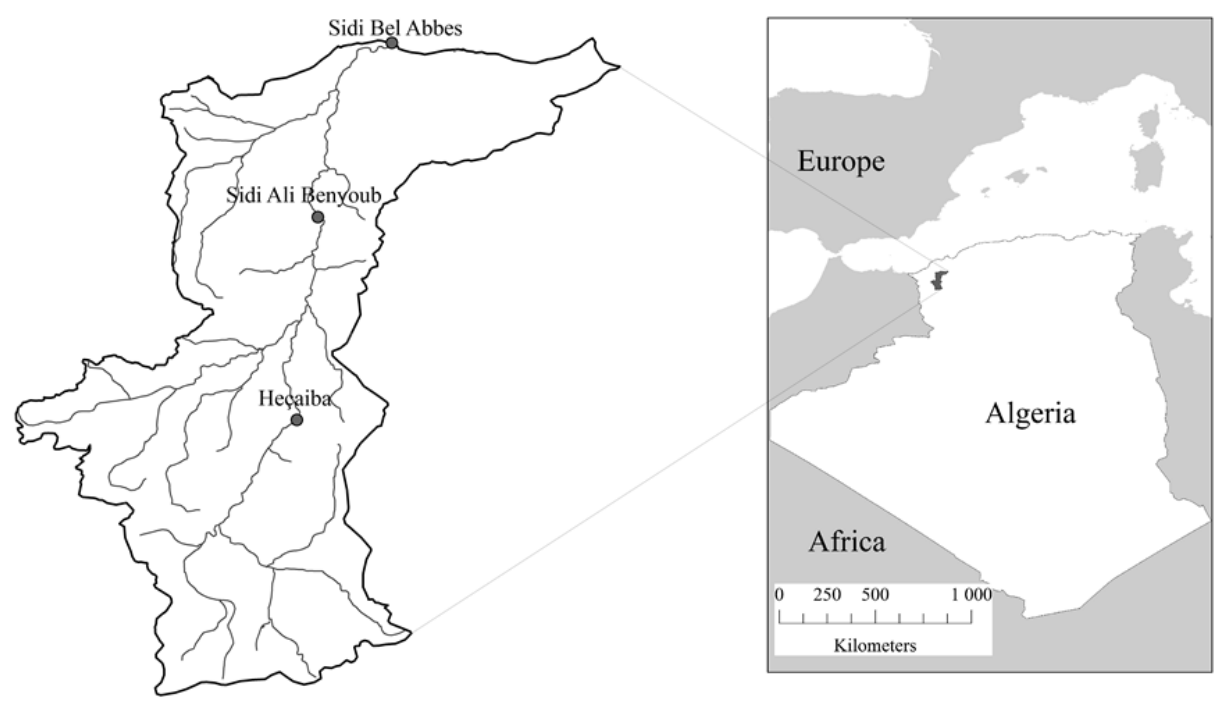

Fig. 1. Location of the Wadi Mekerra River basin; source: own elaboration 


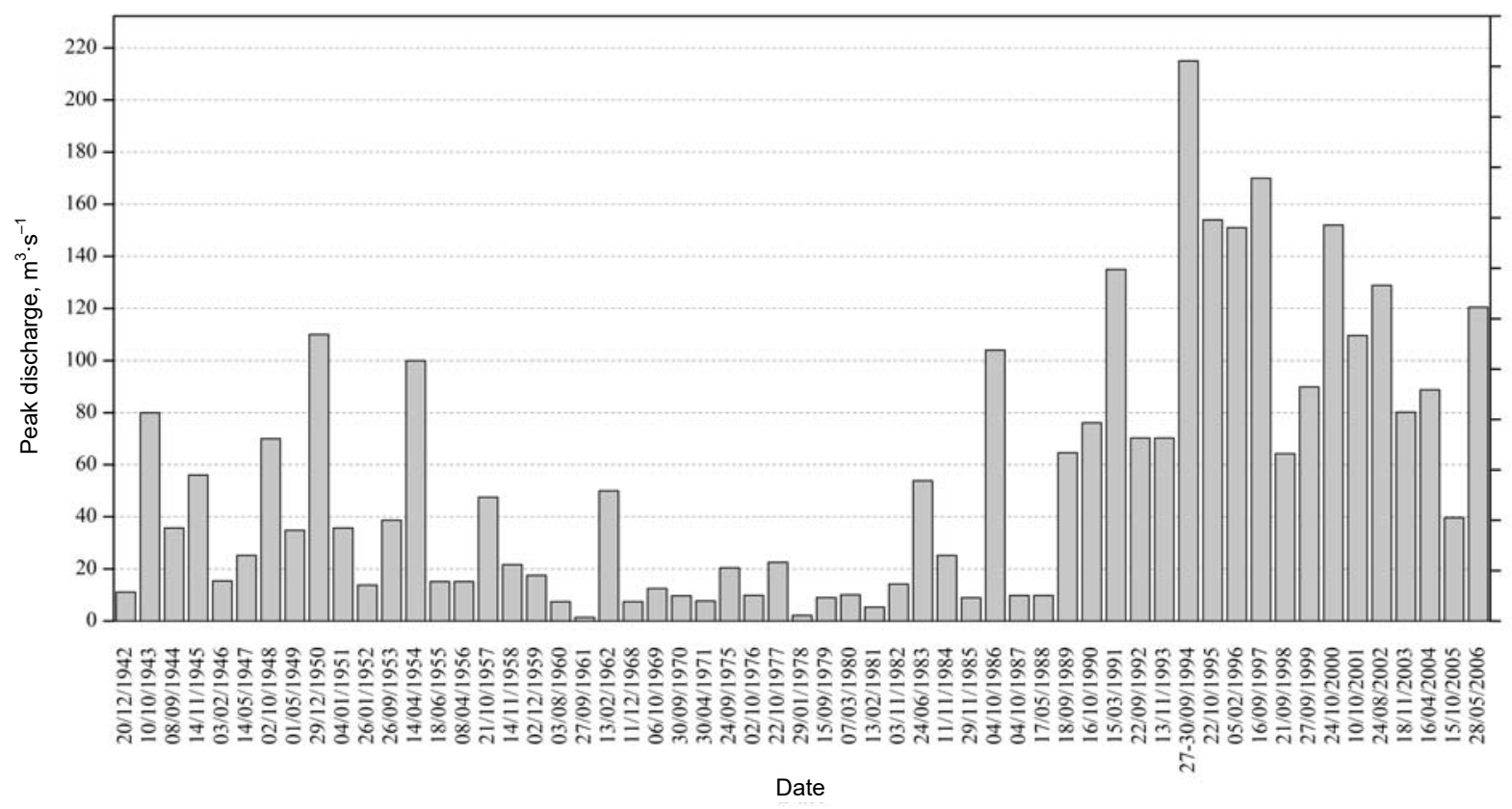

Fig. 2. Peak annual discharges of historic floods measured between 1942 and 2006 at Sidi Bel Abbes gauging station; source: own elaboration

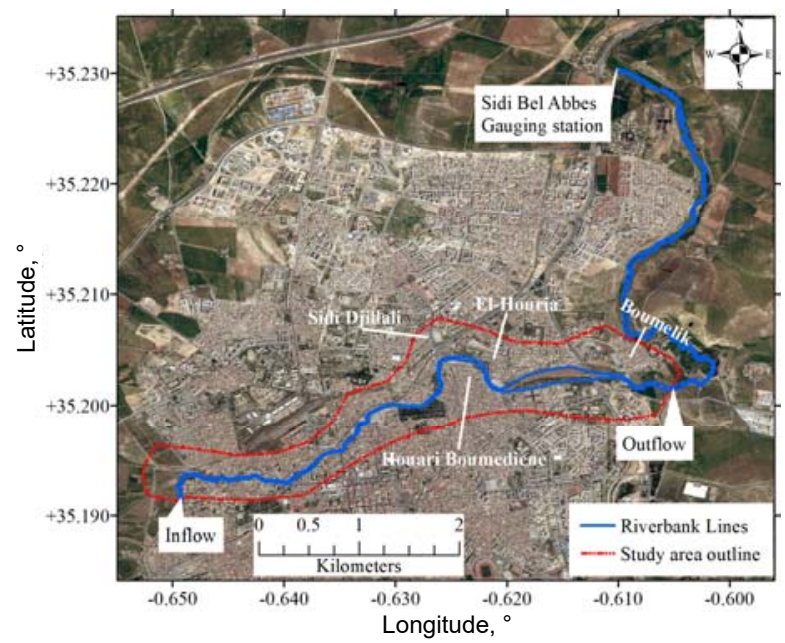

Fig. 3. Location map of the studied reach shown in WGS84 decimal geographical coordinates system; source: own elaboration

$4.53 \mathrm{~m}^{3} \cdot \mathrm{s}^{-1}$ with a maximum value of $215 \mathrm{~m}^{3} \cdot \mathrm{s}^{-1}(\mathrm{reg}-$ istered in September 27-30, 1994) and a minimum value of $0.083 \mathrm{~m}^{3} \cdot \mathrm{s}^{-1}$ (registered in February 11, 1999).

The studied reach is a section of Wadi Mekerra River through the city of Sidi Bel Abbes. Figure 3 represents the reach location on a photo from Google Earth and the limits of the mesh area used in the calculation. This figure was created using the composite of multiple downloaded Google Earth images that were georeferenced in QGIS 2.14 (free; http://www. qgis.org), using the World Geodetic System of 1984 (WGS84) geographic coordinate system (the same geographic coordinate system used in Google Earth). The reach with a length of approximately $5380 \mathrm{~m}$ contains several meanders, the width varying from 13 to $142 \mathrm{~m}$ with low slope of $0.3 \%$.

\section{EQUATIONS}

The governing equations of flow processes are the two-dimensional Saint-Venant equations for shallow water flow which are obtained by integrating the Navier-Stokes equations over the flow depth with the following assumptions: incompressible fluid, small bottom slope, uniform velocity distribution in the vertical direction and hydrostatic pressure distribution. These equations can be written in conservation, vector form as [YING et al. 2009]:

$$
\frac{\partial \mathbf{U}}{\partial t}+\frac{\partial \mathbf{E}(\mathbf{U})}{\partial x}+\frac{\partial \mathbf{G}(\mathbf{U})}{\partial y}=\mathbf{S}
$$

where

$$
\mathbf{U}=\left(h, q_{x}, q_{y}\right)^{\mathrm{T}}
$$

is the vector of conserved variables,

$$
\begin{aligned}
& \mathbf{E}(\mathbf{U})=\left(q_{x}, \frac{q_{x}^{2}}{h}, \frac{q_{x} q_{y}}{h}\right)^{\mathrm{T}} \\
& \mathbf{G}(\mathbf{U})=\left(q_{y}, \frac{q_{x} q_{y}}{h}, \frac{q_{y}^{2}}{h}\right)^{\mathrm{T}}
\end{aligned}
$$

are flux vectors in the $x$ and $y$ directions respectively, and

$$
\mathbf{S}=\left(0,-g h \frac{\partial z}{\partial x}-g h S_{f x},-g h \frac{\partial Z}{\partial y}-g h S_{f y}\right)^{\mathrm{T}}
$$

is the source terms vector.

Where: $h=$ the water depth, $Z=$ the water surface level, $q_{x}$ and $q_{y}=$ the unit width flow rates in the $x$ and $y$ directions, respectively, $u$ and $v=$ the velocity components in the $x$ and $y$ directions, respectively, $g=$ the gravitational acceleration, $t=$ the temporal coordinate; $S_{f x}$ and $S_{f y}$ are the slope friction terms in the $x$ and $y$ directions, respectively. 


$$
S_{f x}=\frac{n_{m}^{2} q_{x} \sqrt{q_{x}^{2}+q_{y}^{2}}}{h^{10 / 3}} ; S_{f y}=\frac{n_{m}^{2} q_{y} \sqrt{q_{x}^{2}+q_{y}^{2}}}{h^{10 / 3}}
$$

and $n_{m}$ is the Manning's roughness coefficient.

Equation (1) can be written in a vector form as

$$
\frac{\partial \mathbf{U}}{\partial t}+\nabla \mathbf{F}=\mathbf{S}
$$

Where: $\mathbf{F}=(\mathbf{E}, \mathbf{G})$ is the flux function matrix.

In this paper, the Saint-Venant equations were solved by a Runge-Kutta discontinuous Galerkin (RKDG) finite element scheme. The hydrodynamic modelling code is written in the Scilab 5.5.2 programming language (free; http://www.scilab.org). A brief description of the RKDG method for the Saint-Venant equations is given below. Further details can be found in the book of KHAN and LAI [2014].

The computational domain is first divided into triangular elements. Inside an element, the variation of the conserved variables, fluxes, and source terms can be approximated by (the summation notation is assumed)

$$
\mathbf{U} \approx \widehat{\mathbf{U}}=\mathbf{N}_{j} \mathbf{U}_{j}, \widehat{\mathbf{F}}=\mathbf{F}(\widehat{\mathbf{U}}), \widehat{\mathbf{S}}=\mathbf{S}(\widehat{\mathbf{U}})
$$

Where: $\mathbf{N}_{j}=$ a diagonal matrix of interpolation (trial) functions, $\mathbf{U}_{j}=$ the approximations of the conserved variables at vertices.

Equation (7) is multiplied by the weight functions, $\mathbf{N}_{i}$, taken to be the same as the trial functions, $\mathbf{N}_{j}$, for the Galerkin method and the resulting equations are integrated over an element.

$$
\int_{\Omega_{e}} \mathbf{N}_{i} \frac{\partial \widehat{\mathrm{U}}}{\partial t} d \Omega+\int_{\Omega_{e}} \mathbf{N}_{i} \nabla \cdot \hat{\mathbf{F}} d \Omega=\int_{\Omega_{e}} \mathbf{N}_{i} \hat{\mathbf{S}} d \Omega
$$

Substituting the approximation of $U$ and applying the divergence theorem

$$
\begin{gathered}
\int_{\Omega_{e}} \mathbf{N}_{i} \mathbf{N}_{j} \frac{\partial \mathbf{U}_{j}}{\partial t} d \Omega= \\
\int_{\Omega_{e}} \mathbf{N}_{i} \hat{\mathbf{S}} d \Omega-\int_{\Gamma_{e}} \mathbf{N}_{i}(\hat{\mathbf{F}} \cdot \mathbf{n}) d \boldsymbol{\Gamma}+\int_{\Omega_{e}} \nabla \mathbf{N}_{i} \cdot \hat{F} d \Omega
\end{gathered}
$$

Where: $\hat{\mathbf{F}} \cdot \mathbf{n}=$ the numerical intercell flux, calculated using the HLLC (Harten-Lax-van Leer contact wave) approximate Riemann solver (see the work of ESKILSSON and SHERWIN [2004] for further details $) ; \mathbf{n}=\left(n_{x}\right.$, $\left.n_{y}\right)^{\mathrm{T}}=$ an outward unit normal vector at an element's boundary, $\Omega_{e}=$ element area, and $\Gamma_{e}=$ the perimeter of the element.

The integral on the left hand side of equation (10) constitutes the components of the $3 \times 3$ mass matrix $\mathbf{M}$. Obviously, $\mathbf{M}$ is symmetric. The right hand side is noted as $\mathbf{R}$. Therefore, equation (10) can be rewritten as:

$$
\mathbf{M} \frac{\partial \mathbf{U}_{j}}{\partial t}=\mathbf{R} \text { or } \frac{\partial \mathbf{U}_{j}}{\partial t}=\mathbf{M}^{-1} \mathbf{R}=\mathbf{L}
$$

The major problem that has to be involved in flood inundation modelling is the handling of drying and wetting zones. If no special attention is paid, the numerical scheme may cause undesirable numerical instabilities and may produce an unrealistic water depth (infinite or negative) and/or spurious velocity generation. The drying-wetting treatment presented here consists of imposing a sufficiently small depth, $h_{\text {dry }}$, (e.g., $10^{-5}$ ) and zero velocity at the dry nodes [KHAN, LAI 2014; YING et al. 2004].

Water surface gradients in the source term are evaluated using the same procedure described by YING et al. [2009]. The numerical solution is advanced from time step $n$ to $n+1$ by the second-order total variation diminishing (TVD) Runge-Kutta scheme [GotTlieb, SHU 1998] as:

$$
\left\{\begin{array}{c}
\mathbf{U}^{[1]}=\mathbf{U}^{n}+\Delta t \mathbf{L}\left(\mathbf{U}^{n}\right) \\
\mathbf{U}^{n+1}=\frac{1}{2} \mathbf{U}^{n}+\frac{1}{2} \mathbf{U}^{[1]}+\frac{1}{2} \Delta t \mathbf{L}\left(\mathbf{U}^{[1]}\right)
\end{array}\right.
$$

The time step, $\Delta t$, is controlled by the CFL (Courant-Friedrichs-Lewy) conditions, $C$, as follows [FAGHERAZZI et al. 2004]:

$$
\Delta t<C\left(\frac{L_{\min }}{\max \left(\sqrt{u^{2}+v^{2}}+\sqrt{g h}\right) \max \left(1, p^{2}\right)}\right)
$$

Where: $L_{\min }=$ the smallest element edge length, $p=$ the order of the basis function.

In this paper, the modified slope limiter of JAWAHAR and KAMATH [2000] used by several researchers (e.g. KHAN, LAI [2014]; LEE [2014]) in two-dimensional shallow water flows computations is used for achieving oscillation free solution. This slope limiting procedure is very suitable for meshes discretized by triangular elements. The procedure for applying this slope limiter is described by LEE [2014].

\section{INPUT DATA}

The selected area is the most affected part of the city of Sidi Bel Abbes by Wadi Mekerra River flooding (Fig. 3). For the terrain part of the study area, recent topographic survey data were coupled with existent data from detailed topographic maps in order to obtain the digital elevation model with a $10 \times 10 \mathrm{~m}$ grid cell using QGIS (Fig. 4). The horizontal grid is comprised of unstructured triangular elements which were prepared by using the data preparation, analysis and visualization software Blue Kenue (free; http://www.nrc-cnrc.gc.ca). The bathymetric data was loaded in Blue Kenue (as ASCII file with $x, y, z$ coordinates where $x$ and $y$ are in meters and not in decimal latitude/longitude degrees) and mapped (through an interpolator) onto the grid so that each node was assigned with an elevation data. The grid consisting of 8960 nodes and 17434 triangular elements is provided in Figure 5. In this figure the $x$ and $y$ coordinates are transformed in decimal degrees to standardize the presentation of all figures. The studied zone has two areas: the channel area and the flood plain (overbank) area. For the channel area, the mesh is taken as $12 \mathrm{~m}$ and for the other area: $24 \mathrm{~m}$. The edge growth ratio is 1.2 to ensure a smooth size transition. 


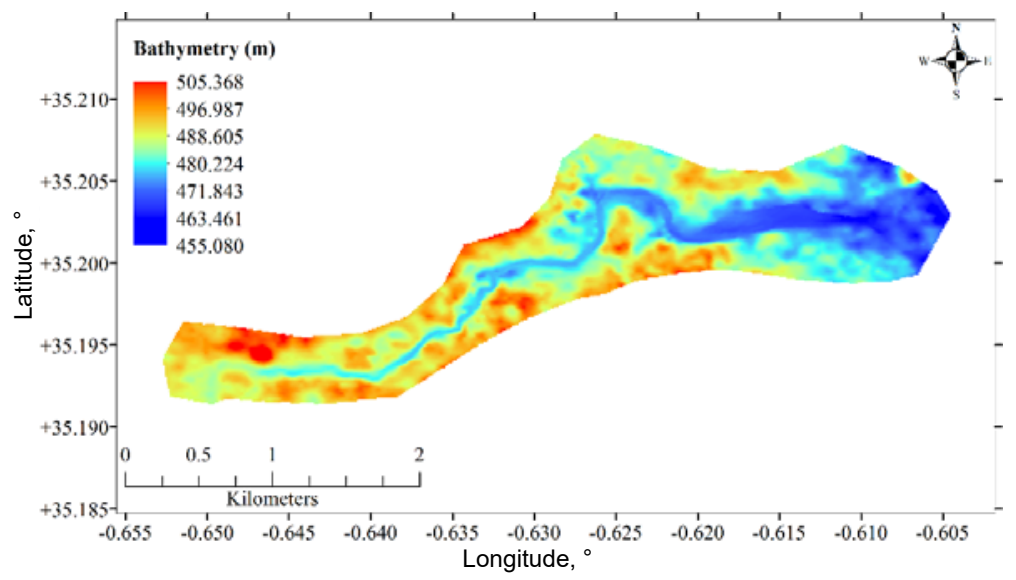

Fig. 4. Topography of the studied reach shown in WGS84 decimal geographical coordinates system; source: own elaboration

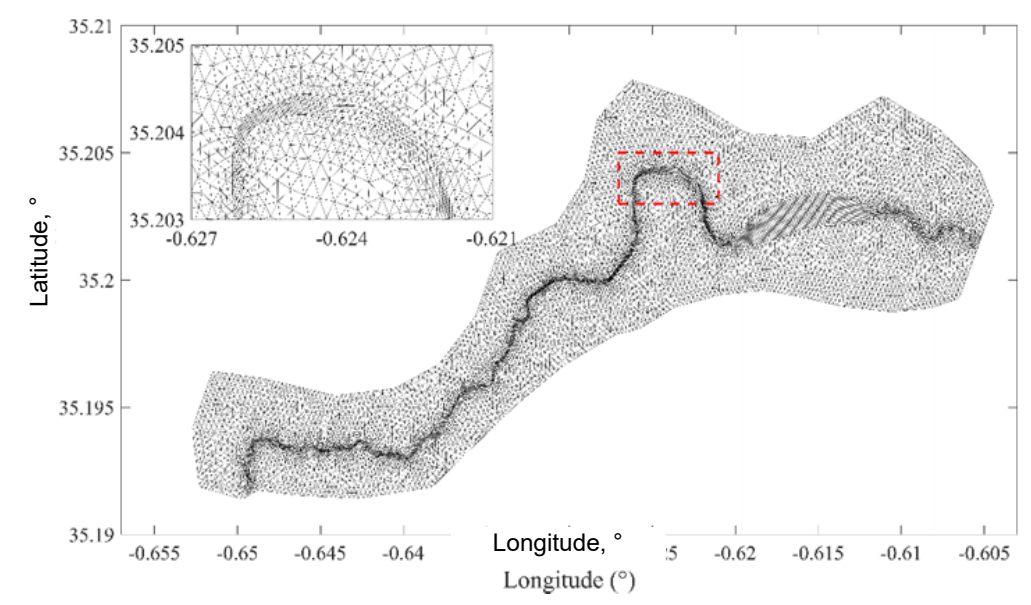

Fig. 5. Finite element mesh developed for the studied reach shown in WGS84 decimal geographical coordinates system; source: own elaboration
1D-2D approach has the advantage that the dynamic flooding could be predicted whilst avoiding the onerous description of the river-bed geometry in 2D and, consequently, achieving a reduction in the computation time [AURELI et al. 2006].

The one-dimensional model based on Saint-Venant equations was solved by the same scheme (RKDG). The model was verified by comparing the computed discharge hydrographs with observed ones at Sidi Bel Abbes gauging station [ATALLAH et al. 2016]. The flood event occurred in October 11, 1995 was used for the calibration. The hydrograph of this flood event is presented in Figure 7. The maximum discharge recorded during this event was 155 $\mathrm{m}^{3} \cdot \mathrm{s}^{-1}$. The topo-bathymetry of the $52 \mathrm{~km}$ reach of Wadi Mekerra River, from Sidi Ali Benyoub to Sidi Bel Abbes gauging stations, was described by using 25 cross-sections [ATALLAH et al. 2016]. The cross-sections used in the computation are interpolated from the available data. For the boundary conditions, we used the observed flow hydrograph at the upstream end of the reach (Sidi Ali Benyoub) and the derived rating curve at the downstream end of the reach (Sidi Bel Abbes).

The channel and the flood plain are initially dry and the channel flow rate is assumed to be zero. The boundary condition is created based on the generated mesh. Boundary conditions consisted of a discharge hydrograph at the upstream inflow and the derived rating curve at the downstream outflow (Fig. 6).

\section{MODEL CALIBRATION}

For the development of hydraulic models, Manning's roughness coefficients are adjusted using recorded water levels and discharges. Stage and flow discharge are measured at Sidi Bel Abbes gauging station located $4.9 \mathrm{~km}$ downstream of the study area. However, the nearest upstream gauging station is located at Sidi Ali Benyoub (42 km upstream from the study area). Therefore, the calibration of Manning coefficient was performed using a hybrid methodology. In particular, we used a one-dimensional (1D) approach to simulate flows into the Wadi, between Sidi Ali Benyoub and the entrance of Sidi Bel Abbes. The obtained hydrograph at the entrance of Sidi Bel Abbes is then adopted as the inflow boundary condition for the $2 \mathrm{D}$ model of the flood-prone area. The
We set the Manning coefficient values considering the results of previous studies [ATALLAH et al. 2016; ATALLAH, HAZZAB 2013] and according to the indications reported in the scientific literature (see e.g. CHOw [1959]) on the basis of the physical characteristics of the Wadi $\left(0.01\right.$ to $\left.0.1 \mathrm{~s} \cdot \mathrm{m}^{-1 / 3}\right)$. The obtained hydrograph at the entrance of flood-prone area is shown in Figure 7.

The 2D model was then used to simulate the flow in the flood-prone area. The mesh was extended down to Sidi Bel Abbes gauging station. With the aim of calibration, water level and liquid flow discharges calculated by the 1D model and water level and liquid flow discharges measured at Sidi Bel Abbes gauging station during the event happened in autumn 1995 were used. Different values of the Manning nonhomogeneous roughness coefficient were tested in the 2D model calibration process: $0.025-0.035 \mathrm{~s} \cdot \mathrm{m}^{-1 / 3}$ for the Wadi Mekerra channel and 0.06-0.1 s $\cdot \mathrm{m}^{-1 / 3}$ for the areas with houses. After simulation and error calculations (between simulated and measured variables), Manning's coefficients were chosen to minimize the errors. The optimal values obtained for the 


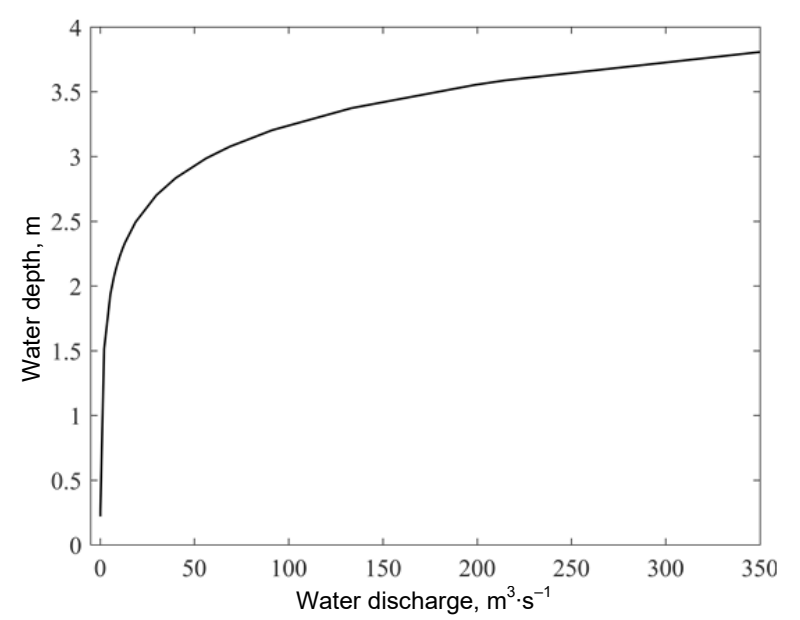

Fig. 6. Rating curve at Sidi Bel Abbes gauging station; source: own elaboration

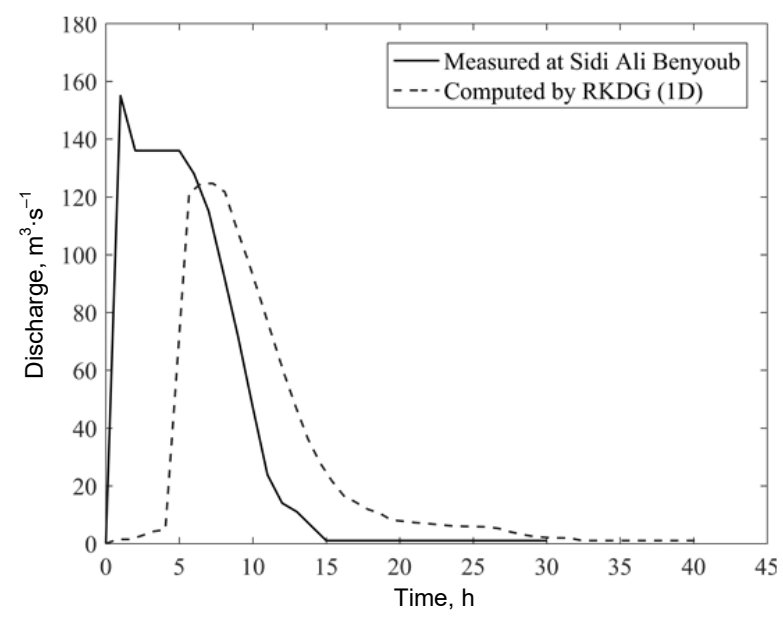

Fig. 7. 1995 autumn flood event: measured hydrograph at Sidi Ali Benyoub and computed hydrograph at the entrance of the study area; source: own study

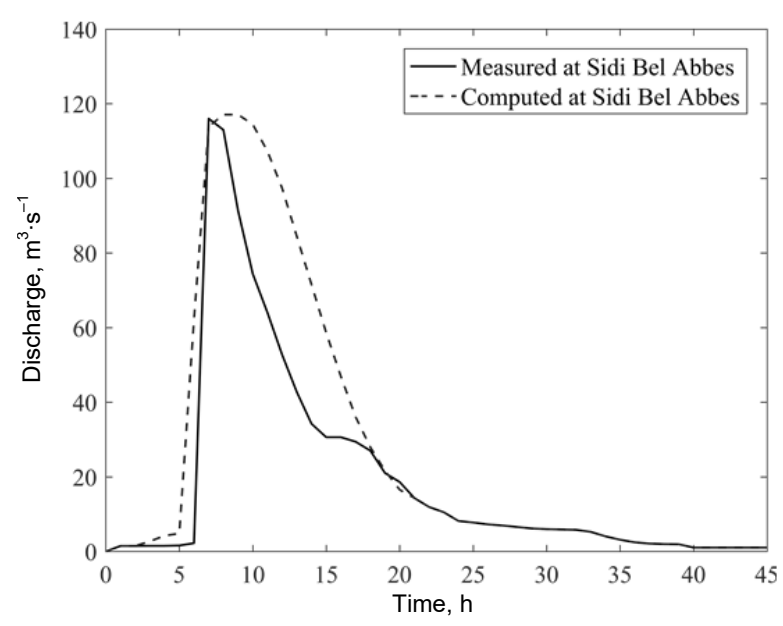

Fig. 8. 1995 autumn flood event: comparison of measured and computed hydrographs at Sidi Bel Abbes gauging station; source: own study

Manning roughness coefficient were $0.028 \mathrm{~s} \cdot \mathrm{m}^{-1 / 3}$ for the channel and $0.071 \mathrm{~s} \cdot \mathrm{m}^{-1 / 3}$ for the areas with houses. Computed and recorded outflow hydrographs for
Sidi Bel Abbes gauging station are displayed in Figure 8 . The results show that the simulated hydrograph was very close to that registered in Sidi Bel Abbes gauging station. The maximum error with these coefficients is less than $1 \%$ for total water discharges were found acceptable.

\section{RESULTS AND DISCUSSION}

After the calibration of the model for the first event of October 11, 1995 (through adjustment of the Manning coefficients), the model was used to analyse the inundation behaviour of Sidi Bel Abbes city during the second flood event occurred between 27 and 30 September 1994. The recorded peak discharge for this flood event at Sidi Ali Benyoub gauging station was about $236.6 \mathrm{~m}^{3} \cdot \mathrm{s}^{-1}$ (Fig. 9). For the same event period, the recorded peak discharge at Sidi Bel Abbes gauging station was about $215 \mathrm{~m}^{3} \cdot \mathrm{s}^{-1}$ and it was the maximum value measured during the period between 1942 and 2006 (Fig. 2). The simulation was performed using the same hybrid methodology described in model calibration.

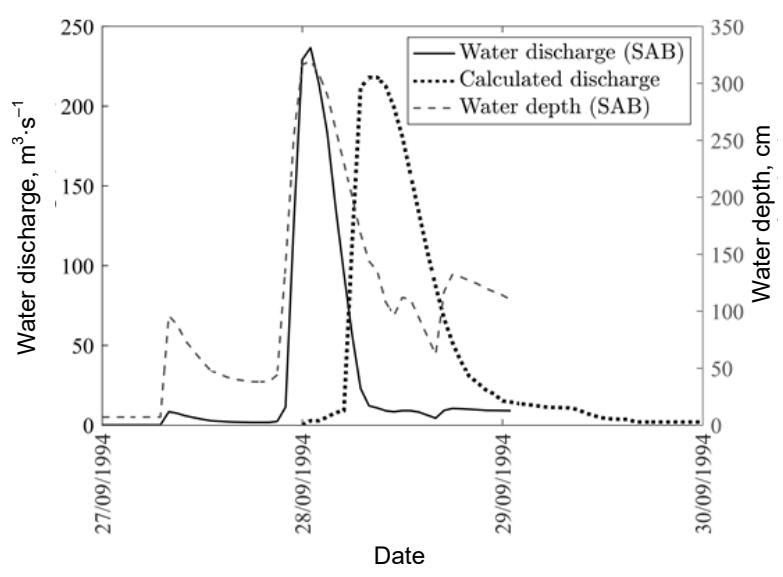

Fig. 9. Water discharge and stage (water depth) hydrographs of the 1994 autumn flood at Sidi Ali Benyoub

(SAB) gauging station and calculated discharge

at the entrance of the study area; source: own study

The simulation is run until the waves had passed out of the domain. The model results of maximum water depths were transformed into inundation maps through QGIS. By superposition of the inundation maps over the city maps one may see inundated houses. This result of the model is very useful for local authorities in order to draw flood risk maps and inform the population. Figure 10a shows the areas that are likely to be inundated under the recorded flood. The slope of the studied section over the upstream reach is about $0.45 \%$, which is steeper than the slope over the downstream reach, which is about $0.15 \%$. Consequently, the inundated area and depth of flow over the upstream reach are relatively lower than corresponding values over the downstream reach. The most affected areas were El-Houria, Sidi Djllali, Houari Boumediene and Boumelik (Fig. 3). The 
flooding of El-Houria, Sidi Djllali and Houari Boumediene areas is caused by the high velocity flows, the narrowing of the flow cross-section and the curvature of the Wadi channel. Naturally, when water flows around a bend, due to centrifugal force, the water level increases near the outer bank than the inner bank. The flow velocity is also faster at the outer bank of the Wadi than the inner bank. This leads to a greater increase in water level towards the outer bank. The velocity distribution map (Fig. $10 \mathrm{~b})$ shows that the event is characterized by very high velocities especially in the first $2 \mathrm{~km}$. The flooding of Boumelik area is due to the increase in water level due to the narrowing of the flow cross-section. The narrowing of the flow cross-section from about $142 \mathrm{~m}$ to about $21 \mathrm{~m}$ would also cause an increase in the velocity of the water. The maximum of water depth in the channel, just upstream of Boumelik area, can reach $12.3 \mathrm{~m}$ which can cause serious damages.

The threat to personal safety and to gross structural damage caused by floods depends largely upon the speed and depth of floodwaters. The greater
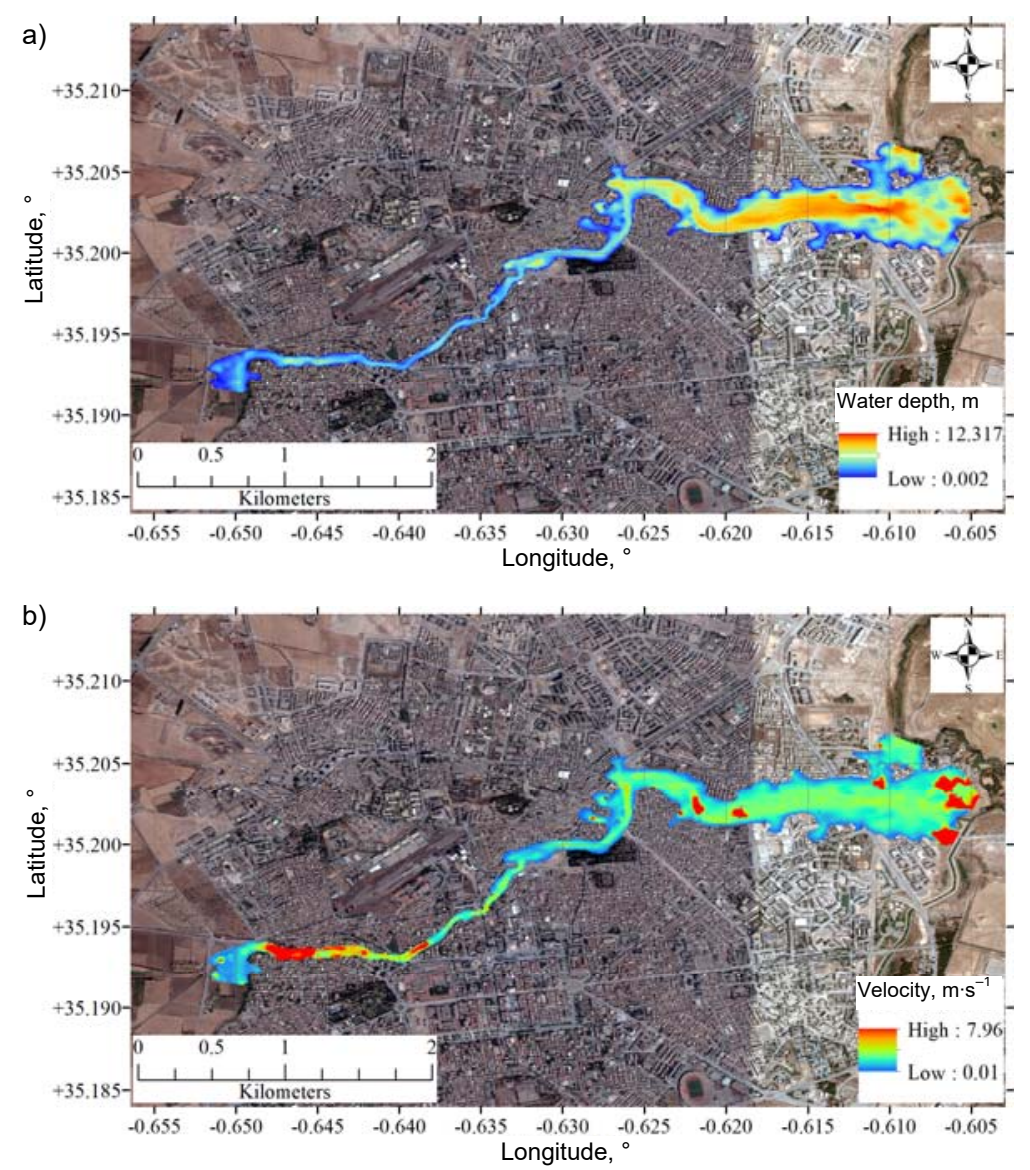

Fig. 10. Distributions water characteristics for the 1994 flood event shown in WGS84 decimal geographical coordinates system: a) maximum water depth, b) maximum flow velocity; source: own study these factors become, the greater the danger to people and property. In order to produce the river flood hazard maps for studied area which is combination of river flood depth and river flood velocity, NSW [2005] flood development manual was applied. As shown on Figure 11 hazard categories are broken down into high, medium and low hazard for each hydraulic category [DERDOUS et al. 2015; NSW 2005].

Figure 12 presents the hazard map resulting from the 1994 flood event. This map was produced in the
QGIS by combining depth and velocity maps according to the diagram presented in Figure 11. The generated river flood hazard in this procedure reflects the effects of both water depth and flow velocity during the flood event. Figure 12 depicts that the largest area is related to high hazard class while the low hazard class has smallest area. The pattern of the river flood hazard maps in Figure 12 proves that the topography of the Wadi and floodplain is an important factor. At the downstream area of the study reach where the

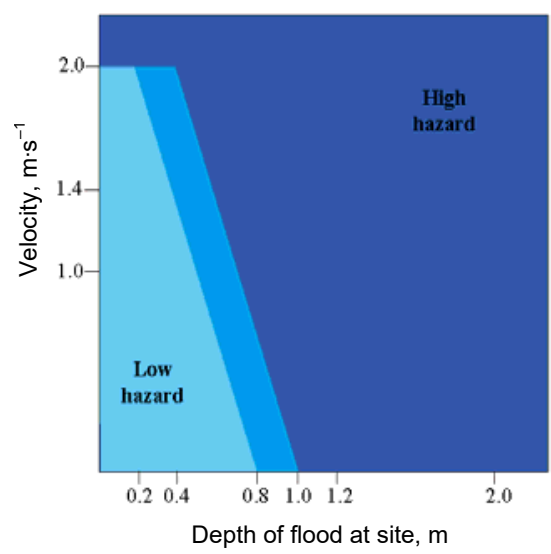

Fig. 11. Flood hazard classification; source: NSW [2005]

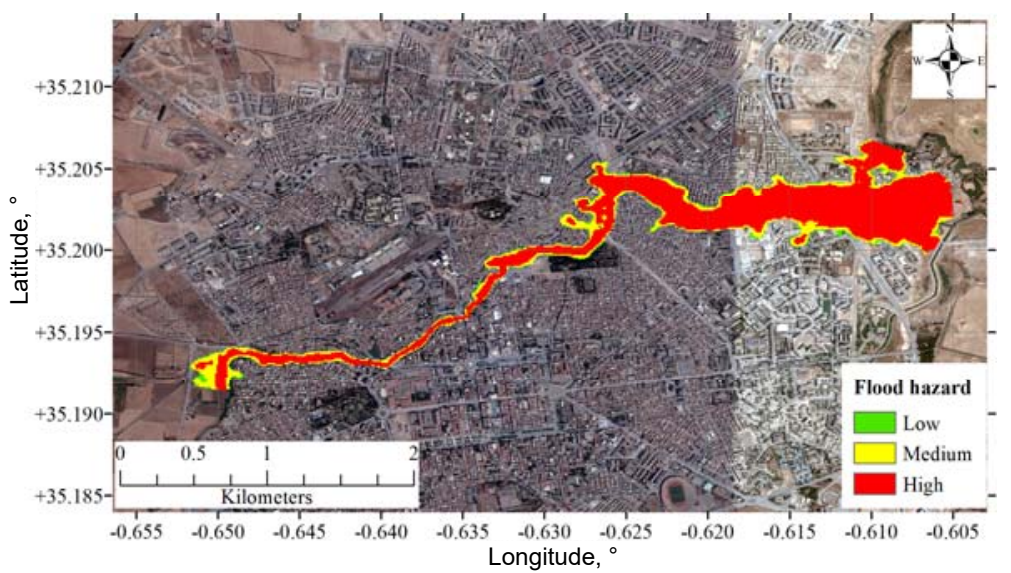

Fig. 12. Flood hazard map for the 1994 flood event shown in WGS84 decimal geographical coordinates system source: own study 
floodplain is relatively lowland the hazard of the Wadi flood is higher than the other locations. During flood event, flood flow exceeds the river banks and overflows to the floodplain.

\section{CONCLUSIONS}

In this study, a section of Wadi Mekerra through Sidi Bel Abbes city was studied by exploiting land and bathymetric surveys and data on liquid flows during two events on October 11, 1995 and September 27-30, 1994 measured in Sidi Ali Benyoub and Sidi Bel Abbes gauging stations. By using the data of the first event (flood of October 11, 1995), the calibration of Manning coefficient was performed using a hybrid methodology; the 1D model in the Wadi to compute stage and discharge hydrographs through the reach, and the 2D model to describe the inundation in the flood-prone area. The simulation of the second flood event was performed using the same hybrid methodology. Computed hydrodynamic parameter values (maximum water depths and velocities) are used to draw flood risk maps. The analysis of these maps led to the following conclusions.

1. The flooding of some areas is caused by the high velocity flows, the narrowing of the flow cross-section and the curvature of the Wadi channel.

2. The topography of the Wadi and floodplain is an important factor of river flood hazard mapping. At the downstream area of the study reach where the floodplain is relatively lowland the hazard of the river flood is higher than the other locations. During flood event, flood flow exceeds the river banks and overflows into the floodplain.

3 . The generated river flood hazard pattern distribution is more influenced by water depth and flow velocity.

For the first time, local authorities may use such a model as a prognosis tool in developing contingency and flood emergency plans and take the appropriate defence measures.

\section{REFERENCES}

Atallah M., HazZab A. 2013. A Petrov-Galerkin scheme for modeling 1D channel flow with varying width and topography. Acta Mechanica. Vol. 224. Iss. 4 p. 707-725. DOI 10.1007/s00707-012-0781-2.

Atallah M., Hazzab A., Seddini A., Ghenaim A., Korichi K.H. 2016. Hydraulic flood routing in an ephemeral channel: Wadi Mekerra, Algeria. Modeling Earth Systems and Environment. Vol. 2. Iss. 182 p. 1-12. DOI 10.1007/s40808-016-0237-0.

Aureli F., Mignosa P., Ziveri C., Maranzoni A. 2006. Fully-2D and quasi-2D modelling of flooding scenarios due to embankment failure. In: River flow 2006: Proceedings of the international conference on fluvial hydraulics. Eds. R.M.L. Ferreira, E.C.T.L. Alves, J.G.A.B. Leal, A.H. Cardoso. 6-8 September 2006 Lisbon, Portugal. Taylor \& Francis Group, UK, ISBN 0-415-408156 p. $1473-1482$.
BERZ G. 2000. Flood disasters: lessons from the past - worries for the future. Proceedings of the Institution of Civil Engineers - Water and Maritime Engineering. London March 2000. Vol. 142. Iss. 1 p. 3-8.

CHOw V.T. 1959. Open-channel hydraulics. New York, USA. McGraw-Hill. ISBN 1932846182 pp. 700.

DELIS A.I., KAMPANIS N.A. 2009. Numerical flood simulation by depth averaged free surface flow models. In: Environmental systems. Ed. A. Sydow. Encyclopedia of life support systems (EOLSS). Oxford. Eolss Publishers. Vol. 3 p. 285.

Derdous O., Djemili L., Bouchehed H., Tachi S.E. 2015. A GIS based approach for the prediction of the dam break flood hazard - A case study of Zardezas reservoir "Skikda, Algeria". Journal of Water and Land Development. Vol. 27. Iss. 1 p. 15-20. DOI $10.1515 /$ jwld2015-0020.

DewAN A.M. 2013. Floods in a megacity: Geospatial techniques in assessing hazards, risk and vulnerability. Dordrecht. Springer. ISBN 978-94-007-5875-9 pp. 199.

ESKILSSON C., SHERWIN S.J. 2004. A triangular spectral/hp discontinuous Galerkin method for modelling 2D shallow water equations. International Journal for Numerical Methods in Fluids. Vol. 45. Iss. 6 p. 605-623. DOI 10.1002/fld.709.

FAgherazZI S., RASETARINERA P., HuSSAINI M.Y., Furbish D.J. 2004. Numerical solution of the dambreak problem with a discontinuous Galerkin method. Journal of Hydraulic Engineering. Vol. 130. Iss. 6 p. 532-539. DOI 10.1061/(ASCE)0733-9429(2004)130:6(532).

GotTlieb S., Shu C.W. 1998. Total variation diminishing Runge-Kutta schemes. Mathematics of Computation. Vol. 67. Iss. 221 p. 73-85. DOI 10.1090/S0025-5718-9800913-2.

JAWAHAR P., KAMATH H. 2000. A high-resolution procedure for Euler and Navier-Stokes computations on unstructured grids. Journal of Computational Physics. Vol. 164 p. 165-203. DOI 10.1006/jcph.2000.6596.

JONKMAN S.N. 2005. Global perspectives on loss of human lives caused by floods. Natural Hazards. Vol. 34. Iss. 2 p. 151-175. DOI 10.1007/s11069-004-8891-3.

KHAN A.A., LAI W. 2014. Modeling shallow water flows using the discontinuous Galerkin method. Boca Raton, Florida, USA. Taylor \& Francis Group, CRC Press. ISBN 9781482226010 pp. 215.

Korichi K.H., HazzaB A., Atallah M. 2016. Flash floods risk analysis in ephemeral streams: a case study on Wadi Mekerra (northwestern Algeria). Arabian Journal of Geosciences. Vol. 9. Iss. 589 p. 1-11. DOI 10.1007/ s12517016-2624-2.

LEE H. 2014. Application of Runge-Kutta discontinuous Galerkin finite element method to shallow water flow. KSCE Journal of Civil Engineering. Vol. 18. Iss. 5 p. 1554-1562. DOI10.1007/s12205-014-0068-3.

NSW 2005. Floodplain development manual: The management of flood liable land. Department of Infrastructure. Planning and Natural Resources. New South Wales Government. Australia pp. L1-L9.

SaInT-Venant A.J.C. 1871. Théorie du mouvement non-permanent des eaux, avec application aux crues des rivières et l'introduction des marées dans leur lit [Theory of unsteady water movement, applied to floods in rivers and the effect of tidal flows]. Comptes Rendus des séances de l'Académie des Sciences. Vol. 73. Iss. 4 p. 237-240.

Sardou M., MaOuche S., Missoum H. 2016. Compilation of historical floods catalog of northwestern Algeria: 
First step towards an atlas of extreme floods. Arabian Journal of Geosciences. Vol. 9. Iss. 6 p. 1-15. DOI 10.1007/s12517-016-2490-y.

SCHUBERT J.E., SANDERS B.F. 2012. Building treatments for urban flood inundation models and implications for predictive skill and modeling efficiency. Advances in Water Resources. Vol. 41 p. 49-64. DOI 10.1016/ j.advwatres.2012.02.012.

YING X., JORGESON J., WANG S.S.Y. 2009. Modeling dam-break flows using finite volume method on unstructured grid. Engineering Applications of Computational Fluid Mechanics. Vol. 3. Iss. 2 p. 184-194. DOI 10.1080/ 19942060.2009.11015264.

YING X., KHAN A.A., WANG S.S.Y. 2004. Upwind conservative scheme for the Saint Venant equations. Journal of Hydraulic Engineering. Vol. 130. Iss. 10 p. 977-987. DOI 10.1061/(ASCE)0733-9429(2004)130:10 (977).

\section{M'hamed ATALLAH, Abdelkrim HAZZAB, Abdelali SEDDINI, Abdellah GHENAIM, Khaled KORICHI}

\section{Mapy zasięgu w przypadku ekstremalnych powodzi: przykład miasta Sidi Bel Abbes w Algierii}

\section{STRESZCZENIE}

Wykorzystano modelowanie hydrodynamiczne do analizy zasięgu ekstremalnych zjawisk powodziowych w mieście Sidi Bel Abbes w północnozachodniej Algierii. Teren badań stanowił odcinek okresowej rzeki Mekerra długości 5,4 km płynącej przez miasto. Badania naziemne i batymetryczne wykorzystano do zbudowania cyfrowego modelu terenu (DTM) koryta rzeki i obszarów zalewowych. Łącząc geometrię z danymi hydrologicznymi, zbudowano dwuwymiarowy model hydrodynamiczny. Model oparto na integracji równań Saint-Venanta (o uśrednionej głębokości) poprzez nieciągły schemat liczbowy Galerkina wg metody RungegoKutty. Model był kalibrowany na współczynnik szorstkości dla zmierzonych wysokości poziomu wody i na odpływ rejestrowany w posterunku pomiarowym Sidi Bel Abbes. Celem pracy było sporządzenie map powodzi w warunkach ekstremalnych zjawisk powodziowych. Wyniki mogą być przydatne władzom lokalnym w podejmowaniu odpowiednich zabiegów ochronnych przed powodzią w przyszłości.

Słowa kluczowe: mapy zalewów, metoda Rungego-Kutty, nieciagly schemat Galerkina, powódź, równania Saint-Venanta, Wadi Mekerra 